\title{
Did Foucault Revolutionize History?
}

\author{
Cody Franchetti \\ Modern European Studies, Liberal Arts Master’s Program, Columbia University, New York, USA. \\ Email: codyfranchetti@gmail.com \\ Received October 15 ${ }^{\text {th }}$, 2011; revised November 14 $4^{\text {th }}, 2011$; accepted November $20^{\text {th }}, 2011$.
}

\begin{abstract}
With the pretext of analyzing Foucault's contribution to history, the paper is an essay on the philosophy of history. It is shaped, fundamentally, as an answer to the historian Paul Veyne's essay, "Foucault Revolutionizes History" (1978) and his assertions on Foucault and historical methodology; Veyne claimed Foucault to have revolutionized the discipline of history thanks to his singular gaze and his profound skepticism. The paper counters Veyne's assertions on both Foucault and Veyne's historiography and seeks to provide a concept of history that is more nuanced and conscious of the human sciences' ontology and duties. To do so, the paper engages with a number of historical currents, thinkers, and concepts, which shape historical inquiry.
\end{abstract}

Keywords: Philosophy of History, Historical Methodology, Nominalism, Hermeneutics, Michel Foucault, Paul Veyne, Marcel Gauchet

\section{Introduction}

In 1978, Paul Veyne, historian, friend, admirer, and confidant of Michel Foucault wrote a famous and controversial essay entitled "Foucault Revolutionizes History". In it, he claimed Foucault to be a new kind of historian-one who by "stripping away the veils", managed like none other to "peel away the banalities and notice that there is more to explain"2 than what was previously understood about a period. Though brilliant, Veyne's reading of Foucault offers only a partial view of him whose thought is more heterogeneous than Veyne's understanding; Foucault invariably wished to defy classification and disparaged any attempt to apply it to him. Foucault was first and foremost a thinker rather than a philosopher, I'd venture to say, for his thought was not resolutely systematic and presented a number of aporias, some of which I shall discuss. Yet his thought and its implications for historical practice, as well as Foucault's own, valuable excursions into history itself, indeed offer fertile cues for historical enquiry. On the other hand, whether Foucault actually was a historian is a question that ought to be considered; it is bound to polarize its enquirers; and it is fated to be especially captious for those who see in Foucault a messianic figure who turned history on its head with his methodology, even though as we shall see, Foucault himself was not necessarily mindful of the true nature of his methodology. But answering the question of whether Foucault was, say, a Febvre, a Bloch - the initiator of a new, veritable historical school-is luckily not the task of this paper. Instead, by examining Veyne's assertions, Foucault's own works, and by finding out whether his was truly an ex-novo historical practice, this essay shall attempt to appraise whether Foucault 'revolutionized' history—and if so, how.

\section{Discussion}

Veyne's argument for Foucault's originality rests chiefly upon three points. The first is that Foucault was both an empiricist and a profoundly skeptical thinker "who believed only in the truth of facts never in the truth of ideas."3 This, according

\footnotetext{
${ }^{1}$ Veyne, 1997: p. 156.

${ }^{2}$ Veyne, 1997: p. 156

${ }^{3}$ Veyne, 2010: p. 1.
}

to Veyne, allowed Foucault to avoid the pitfalls of relativism and historicism - to pierce through the "banalities" of the "vague and noble terms"4 often used by other historians to portray an age, and to display "people's practices as they really are." 5 The evocation of Ranke's famous dictum ("wie es eigentlich gewesen”) by a modern historian like Veyne is surprising: Ranke was the embodiment of the great German historical school of the nineteenth century, which sought to reconstruct the past empirically by working exclusively from original documents and archives: "Ranke ended by holding that it is not science to extract modern history from anything less than the entire body of written evidence." 6 The limitation of writing history solely on empiricist principles was archly described by Jaques Barzun: "It had been a delusion to suppose with Ranke and his school that history had become scientific: it had merely become blindly exhaustive about past politics: it produced what was wittily called 'biennial history'-a lifetime of research to furnish an account of two years in a bygone era, preferably remote."7 In fact, the conceit that the past can be scientifically reconstituted 'as it really was' has long been abandoned by historians; yet, Ranke represents a giant step in the history of historiography and remains a paradigm for any historian. Be that as it may, Veyne finds in Foucault's skepticism-an empiricist stance - that fundamental quality, which according to him enables Foucault to circumvent other historians' incomplete ambiguities. Of course, we must establish whether Foucault actually was an empiricist, or whether Veyne is projecting his own vision of history onto his admired colleague.

The second attribute, which according to Veyne propels Foucault's historical capacity farther than other historians, is nominalism. Veyne's argument is essentially that the belief in universals hampers an historian's understanding of a period in its uniqueness.

"In short, in any given era the set of practices gives rise, on a given material point, to a unique historical countenance in which we think we recognize what is called, in vague terms, historical science or religion; but what takes shape at that same point in another era will have its own unique and very different

\footnotetext{
${ }^{4}$ Veyne, 1997: p. 15.

${ }^{5}$ Veyne, 1997: p. 156

${ }^{6}$ Acton, 1886: p. 16

${ }^{7}$ Barzun, 1974: p. 5 .
} 
countenance and, conversely, a countenance vaguely similar to the earlier one will take shape at a some other point. This is what denying the existence of natural objects means: across the ages we do not encounter the evolution or modification of a single object that always appears in the same place.”8

A few pages later, Veyne drives the point to its paroxistic locus: "there is no concrete trans-historical truth"9. We shall have to examine closely the value of sober nominalism as opposed to its deceitfulness when relied upon excessively.

Lastly, Veyne considers Foucault's concepts of "practice" and "discourse" as completely new domains for historical invest tigation: "The Foucault-style genealogy-history completely fulfills the project of traditional history; it does not ignore society, the economy, and so on, but it structures this material differently - not by centuries, peoples, civilizations, but by practices."10 This statement shall also need to be examined to determine whether these concepts were new or whether they were already intrinsically part of other historians' understanding - albeit under a different name. These are in synthesis Veyne's arguments for Foucault's revolutionizing history.

Let us first look at whether Foucault was in fact an empiricist; Veyne's impassioned reading of him is certainly slanted in that direction. Foucault displayed positivist leanings when he wrote that understanding historical change, "is a question of what governs statements, and the way in which they govern each other to constitute a set of propositions that are scientifically capable of being verified or falsified by scientific procedures."11 This extract comes from an interview in June 1974, when Foucault, under the spell of Nietzsche, especially his philosophy concerning genealogy and power, had turned his interests to relations of power on the broadest terms. During this period, he looked to forge a historical method that incorporated these concepts and seemed intent upon systematizing his view of history. "Good historical method requires us to counterpose the meticulous and unavowable meanness of these fabrications and inventions [ideals, poetry, religion, etc.], to the solemnity of origins."12 Here Foucault's move was to adopt Nietzsche's conceit that ideals did not have an origin-they were not born out of a volcano-but were rather manufactured in the great 'factory of the human mind' at some point or another (as propounded in Genealogy of Morals). Foucault found Nietzsche's distinction between Ursprung (origin) and Erfindung (invention) extremely valuable: that religion and poetry, for example, did not have an origin but were invented allows, in Foucault's view, to examine these domains with a certain degree of empiricism, because the advent of, say, poetry, with its "curious idea of using a certain number of rhythmic or musical properties of language" 13 , can be situated at a certain point in time (with the collective evidence we have) thus allowing for a scientific-and possibly reassuring_view when penetrating the historicity of these domains. However, I'm afraid that this is the extent of Foucault's authentic and legitimate empiricist enterprise.

But Foucault claimed an empirical stance as early as 1966, in The Order of Things: "History from the nineteenth century, defines the birthplace of the empirical, that from which, prior to all established chronology, it derives its own being. History becomes an empirical science of events and that radical mode

\footnotetext{
${ }^{8}$ Veyne, 1997: p. 171.

${ }^{9}$ Veyne, 1997: p. 171.

${ }^{10}$ Veyne, 1997: p. 171.

${ }^{11}$ Foucault, 2000b: p. 114.

${ }^{12}$ Foucault, 2000b: p.7.

${ }^{13}$ Foucault, 2000b: p.7.
}

of being that prescribes their destiny to all empirical beings, to those particular beings that we are." ${ }^{\text {T4 }}$ This creed—an empirical Weltanschauung, where we ourselves are "empirical beings"is not to be taken at face value, at least not in The Order of Things, for two fundamental reasons. The first is that if this book is empirical in its outlook, too many empirical inaccuracies litter its "scientific" postulations. I shall provide but two examples. The Order of Things, fundamentally, deals with the gradual but inexorable disappearance of the law of similitude that governed language during the Renaissance. Foucault charts the substitution of representation in place of similitude (in the seventeenth and eighteenth centuries), which in turn was subverted in the nineteenth century: general grammar; the realist, naturalistic vision of life-life and work; a bourgeois life whose imperatives are a realistic perception of existence, which is encumbered by the weight of finitude; all contribute to representation's demise. And so, Foucault states that,

"What came into being with Adam Smith with the first philologists is a minuscule but absolutely essential displacement, which toppled the whole Western thought: representation has lost the power to provide a foundation No composition, no decomposition, no analysis into identities and differences can now justify the connection of representation."15

The appearance of Schopenhauer's The World as Will and Representation in 1818 and its increasing success during the second edition of 1844 and its resounding triumph of its third, in $1859^{16}$ discredits Foucault's argument that representation 'lost the power to provide a foundation' or that there was a disconnect between representation and thought in the nineteenth century altogether. A second example I wish to give of an 'empirical' falsity in the book, which is 'scientifically verifiable' is Foucault's statement that "until the nineteenth century, analyses of language show little change. Words are still investigated on the basis of their representative values, as virtual values that prescribes one and the same mode of being for them all.” In Germany, Herder, whom Foucault never even mentions in the book, profoundly changed the study of language, annihilating the hegemony of the French language by declaring language's adjacency to national culture, and, therefore, intimating all languages to be equal, by studying language in its own accord; in England, William Ward, in 1765 and 1777, published what is considered the first modern book of grammar ('natural grammar' as Foucault would call it) whose influence can be traced to modern linguistics ${ }^{17}$, and, Adam Smith himself wrote in 1761 an important treatise on the origin and development of language. Clearly, the investigation of language in its own principles and rules, divested from its 'representational value', had started well before the nineteenth century and quite significantly so.

The second and most flagrant evidence that The Order of Things, as well as Foucault's thought in general, cannot be considered empirical, is its underlying hermeneutical stance. It is my contention that Foucault was in reality a hermeneutic thinker: an unequivocal, magnificent example of a hermeneutic approach may be found in the following passage, again from The Order of Things, "Literature becomes progressively more differentiated from the discourse of ideas, and encloses itself

\footnotetext{
${ }^{14}$ Foucault, 1994: p. 219.

${ }^{15}$ Foucault, 2000b: p. 238-239.

${ }^{16}$ A connection with Schopenhauer's late success may be found in the dramatic weakening of Hegel's influence after the revolutions of 1848.

${ }^{17}$ See unpublished dissertation by Pankhurst, J. (1966) William Ward's Essay on Grammar: a Critical Account and an Assessment of its Relevance to Eighteenth and Twentieth Century Linguistics. London University.
} 
within a radical intransitivity; it becomes detached from all the values that were able to keep it in general circulation during the Classical age (taste, pleasure, naturalness, truth), and creates within its own space everything that will ensure a ludic denial of them (the scandalous, the ugly, the impossible); it breaks with the whole definition of genres as forms adapted to an order of representations, and becomes merely a manifestation of language which has no other law than that of affirming-in opposition to all other forms of discourse-its own precipitous existence; and so there is nothing for it to do but to curve back in a perpetual return upon itself, as if its discourse could have no other content than the expression of its own form; it addresses itself to itself as a writing subjectivity, or seeks to re-apprehend the essence of all the literature in the movement that brought it into being." 18

This extraordinary passage, which describes the scission between language and literature in the nineteenth century, when the literary works of writers became testament to literature's independence from language - to which it was hitherto fused-and were thus irrevocably engaged in a discourse, which literature started undertaking about itself, is a modern hermeneutics tour de force. Modern hermeneutics, which is based on Schleiermacher's idea of the 'circle of understanding' (Zirkel in Verstehen) is employed with great élan by Foucault: to understand and interpret - the hermeneutic act, in fact-creation of literature as an independent domain, Foucault uses the 'circle of understanding' by mediating between the part and the whole, and, the whole and the part, in a constant gyrating motion, which produces understanding, and, ultimately, as Hans Georg Gadamer would say, truth. And there is indeed a great deal of truth in Foucault's observation about the newfound, autonomous position of literature in the nineteenth century.

So the empiricist viewpoint does not encapsulate Foucault's thought after all despite his stating the contrary. In fact, in the same year that The Order of Things was first published, a seemingly different Foucault said that the human sciences "are caught, as it were, in a double obligation, a simultaneous postulation: that of hermeneutics, interpretation, exegesis." ${ }^{9}$ This statement, if confronted with that from 1974 where Foucault insisted on the need that scientific procedures be employed to detect historical change, as well as the affirmation of empiricist methods, are countered endlessly by the performance of hermeneutics throughout The Order of Things. This gives rise to a crucial aporia: a choice must be made between hermeneutic and scientific knowledge, for a hermeneut cannot be an empiricist. This was demonstrated most powerfully by Gadamer in Truth and Method; Gadamer revealed hermeneutics to be an ulterior form of knowledge bearing truth outside Method-the indefeasible foundation of natural science. It is obvious that we ought to recognize that Paul Veyne's fancy that "[Foucault] this supposed sixty-eightist, was an empiricist" 20 is untenable on this contradiction alone. It seems to me that Foucault's putative strict empiricism may be put to rest.

Foucault's inaccurate appraisal of his own epistemology should not detract from The Order of Things' stature; after all, Walter Benjamin spoke of the often occurring author's delusion: "as if the creator were, just because he created it, also the best interpreter of his work-this has been called 'empathy', in an attempt to provide a disguise under which this fatal, pathological suggestibility masquerades as method."21 The Order of

\footnotetext{
${ }^{18}$ Foucault, 1994: p. 300.

${ }^{19}$ Foucault, 2000a: p. 263.

${ }^{20}$ Veyne, 2010: p. 2.

${ }^{21}$ Benjamin, 1977: p. 53.
}

Things remains an enormously fascinating book, one of the cardinal books of the second half of the twentieth century, and a book whose insights and cues easily assign Foucault into the Pantheon of the great cultural figures of his period. We should therefore not unduly worry whether Foucault's estimation of his own work was faulty; nothing is diminished by it.

Next, we come to Veyne's nominalism and his belief that this perspective invigorated Foucault's historical capabilities substantially. Marcel Gauchet fulminated Veyne for his extreme nominalist position; in an article called Le nominalisme historien. A propos de "Foucault révolutionne l'histoire" de Paul Veyne, Gauchet noticed a radicalization of Veyne's nominalism in describing Foucault's merits. Gauchet did not concern himself at all to assess whether Veyne's labeling Foucault as a nominalist was legitimate, and ignored Foucault all together (quite tellingly, as we shall see later). He did concede, however, that nominalism has its own, rightful place in the process of writing history: "history [is] the emergence, the advent of forms than cannot be explained, except by missing what matters in them, that is, what these forms have that is incomparable. From this comes the necessity of the historian's nominalism, the only position that can adequately open him to the inexplicable singularities of a process of permanent innovation.,22

But he finds Veyne's nominalism "in flagrant contradiction with the demands of his pretended nominalism"23, because "Veyne does refrain from abolishing things that do not exist" ${ }^{\text {"2 }}$. Gauchet thus sees in Veyne an exaggerated nominalism, blinded to real historical understanding: "The nominalist shall always be deceived by the illusion of realism, which is always more nominalist than he." 25

Gauchet's criticism of Veyne is significant for our purpose, because Foucault was a nominalist, but not as extreme as Veyne. Gauchet expounded brilliantly on the value that the disbelief in universals may have in historical enquiry. But the fruits of sound nominalism are not new: Herder had already "set a universal historical worldview against the Enlightenment's teleological view of history to acknowledge that each period has its own right to exist, in its own perfection." ${ }^{26}$ But more importantly, Gauchet's warning that an exclusively nominalist outlook has serious drawbacks for the historian is sensible, I think. It is a fact, as Fustel de Coulanges said, that "History is not the accumulation of facts and events of every sort that have been produced in the past: it is the science of human societies"27 and as such, one must be aware that, contrary to the nominalist position, there are constants in human nature-vanity, rapacity, the wish for a better position in society, lust, love: some human traits are without a doubt trans-historical. And the historian who disregards human essences shall not set them against the period that he is studying-which is of course exemplary and unrepeatable-thus

\footnotetext{
$\overline{{ }^{22} \text { ["l'histoire qui est le surgissement, l'avénement de formes qui ne saurient }}$ s'expliquer, sauf à manquer ce qui compte en elles, à savoir ce que'elles comportent d'incomparable. D'où le nécessaire nominalisme de l'historien, seul à meme de l'ouvrir adéquatement aux singularités inexplicables d'un processus d'innovation permanente.”] Gauchet, 1986: p. 403.

${ }^{23}$ ["en contradition flagrante avec les requisitions de son prétendu nominalisme.”] Gauchet, 1986: p. 414.

${ }^{24}$ ["Veyne ne se contente pas d'abolir des choses qui n'existent pas."] Gauchet, 1986: p. 414.

${ }^{25}$ ["Le nominaliste sera toujours pris en défaut d’illusion réaliste par plus nominaliste que lui.”] Ibid, p. 411.

${ }^{26}$ Gadamer, 2004: p. 198.

${ }^{27}$ ["La storia non è l'accumulazione degli avvenimenti d'ogni tipo che si sono prodotti nel passato: essa è la scienza delle societá umane.”] Bloc, 2005: p. 71. Marc Bloc cited this formula in his last, scattered papers on history, written just before being shot in 1944 by the Gestapo.
} 
finding his compass of vision considerably diminished by such heedlessness.

The third and last point which Veyne envisions as a completely novel mode that Foucault pointed us to for a superior understanding of history (or in Veyne's own words 'structuring history'), is "practices": "I tried to do a historian's work by showing the simultaneous practices and the transformations that accounted for their visible changes. ${ }^{28}$ But, as it turns out, a number of great historians who preceded Foucault had had the very same concept in mind. Marc Bloch's The Royal Touch (1924) was one of the first history books not to be confined to a single period, since, as one of the founders of the Annales School, he developed the famous concept of 'la longue durée'. Bloch's approach, like Foucault's, was highly interdisciplinary and the book was concerned with the practices spanning for centuries of those who believed in the thaumaturgic properties of kingship. He frequently spoke of "collective representations", a concept which clearly abuts with Foucault's "practices”. Thus, Foucault's concept of practices was not new. And yet, his application of it in one of the greatest themes in European history-the rise of the modern state is of striking consequence: "the state effectively entered into the reflected practice of people at a given moment, the way which, at a given moment, the state became for those who governed, for those who advised governors, for those who reflected on governments and the action of government as they saw it, was without a doubt not the absolutely determinant factor in the development of the state apparatuses, which in truth existed well before-the army, taxation, justice-but was absolutely essential, I think, for the entry of all these elements into the field of an active, concerted, and reflected practice that was, precisely, the state. We cannot speak of the state-thing as if it was a being developing on the basis of itself and imposing itself on the individuals as if by spontaneous, automatic mechanism. The state is a practice. The state is inseparable from the set of practices by which the state actually became a way of governing, a way of doing things, and a way too of relating to government." 29

At the end of the book, Foucault further advocates that "it must be possible to do the history of the state on the basis of men's actual practices, on the basis of what they do and how they think." ${ }^{30}$ So although Foucault's idea of 'practices' applied to historical understanding may not be original, it is used here with driving force.

Foucault's latter quote displays a startlingly close resemblance to "mentalité", a concept which also had a distinguished antecedent: Erwin Panofsky. Panofsky’s Gothic Architecture and Scholasticism first introduced a broader, hermeneutic view of iconography, which until his book, was an approach that attempted to uncover a world-view of a culture by studying the symbols and images of the art of a period. In the book, Panofsky saw a parallel between Thomas Aquinas's scholastic philosophy and the appearance of Gothic architecture: they both arose at the same time and around the same place (Paris). As Peter Burke aptly described, "the connection he discussed [was] not in terms of the 'spirit of the age' but, more precisely, in terms of the spread from philosophy to architecture of what he calls a "mental habit", or habitus, a cluster of assumptions about the need for transparent organization and the reconciliation of contradictions." ${ }^{31}$ In short, Panofsky was focusing on the mentality of a period (or mentalité). This concept shall bridge us to other aspects of Foucault that Veyne did not dis-

\footnotetext{
${ }^{28}$ Michel Foucault, 2000a: p. 292.

${ }^{29}$ Foucault, 2007: p. 276-277.

${ }^{30}$ Foucault, 2007: p. 358.

${ }^{31}$ Burke, 2008: p. 13.
}

cuss but which are considered fundamentally Foucaultian qualities and thus ought to be examined.

So far we have seen that some of the traits, such as "practices" which Veyne thought Foucault possessed, were not new and thus not "revolutionary", and, that Veyne assigned to Foucault a strict empiricist's point of view erroneously. That Foucault was a nominalist may be certainly granted to Veyne, but we have also seen, I hope, that a sagacious historian will follow the nominalist view without excess. Foucault's epistemology, therefore, was different from what Veyne claims. We shall now look at a few other concepts that are unquestionably-and indissolubly—associated with Foucault's thought: "episteme" and "discontinuity". I ended the section of Veyne's list of Foucault's purported revolutions in history with Panofsky's concept of mentalité as somewhat similar to "practices", because I think that the concept of mentalité may have been the germidea which gradually swelled to "episteme"; Foucault was surely acquainted with mentalité through the Annales School, which absorbed it in its own vocabulary and epistemology. ${ }^{32}$ Clearly, episteme is a far richer concept than mentalité, for it is "the total set of relations that unite, at a given period, the discursive practices that give rise to epistemological figures, sciences, and possibly formalized systems ${ }^{\prime 33}$ and is thus considerably more wide ranging, allowing for a deeper understanding of all the interrelations of a period. For example, Foucault's tracing in The Order of Things of the gradual loss of representation's significance through the seventeenth and eighteenth centuries until it spoke no more to the modern man, is an instance of this greater and deeper perspective when compared to Tim Blanning's roughly similar explanation for the baroque's impenetrability to our modern eyes, "the dominant culture was representational That is perhaps why later ages, more attuned to secular literalism and humanist understatement, have often found the confident resplendence of the baroque uncongenial. ${ }^{34}$ In this instance, we can confidently agree with Veyne that in contrast to Blanning, Foucault "peeled away the banalities and noticed that there was more to explain" instead of referring to historical awareness "in vague and noble terms"; "secular literalism" and "humanist understatement" sound as adorned but hollow statements next to Foucault's pertinent, audacious yet precise metaphoric language throughout The Order of Things.

If, as I see it, Panofsky represents an important station in the development of episteme, then we ought to consider that he, too, was not the sole historian who tried to look through the eyes of a period's knowable possibilities. Ortega y Gasset had written in 1935 that "The diagnosis of any human existence, whether of an individual, a people, or an age, must begin by establishing the repertory of its convictions. It is man's beliefs that truly constitute his state.”35 The epistemological landscape is a familiar one-and it is not far from Foucault's own.

There was however an earlier, eminent historian whom I consider Foucault's antecedent in many respects, although their similarity may not be at all evident. Johann Huizinga was a historian who was part of the revolt against rationality in the human sciences, the nineteenth century revolt that was commenced by Helmholtz and Bergson, which sought a non-em-

\footnotetext{
${ }^{32}$ For a brief but indicative description of the ambiguous relationship between Foucault and the Annales School, see Burke, P. (1990). The French Historical Revolution. Stanford: Stanford University Press. (especially p. 103).

${ }^{33}$ Foucault, 2010: p. 191.

${ }^{34}$ Blanning, 2007: p. 458.

${ }^{35}$ Ortega y Gasset, 1936: p. 283.

${ }^{36}$ Weintraub, 1966: p. 228.
} 
pirical approach to history, in the belief that history is an essentially humanistic pursuit. Huizinga believed that "history is a cultural form and fulfills a function in culture." 36 He was an exponent of what is now referred to as "classic cultural history", 37 and envisioned "the ultimate object of the historian [to be] culture as a whole, the broadest historical object. His knowledge consists of cultural forms and functions. The historian's basic question should always be concerned with the place and function of the separate subject in the broader cultural context." 38 And he often repeated that "culture exists only as a whole”39. He even had the idea, which was quite unheard of at the turn of the century-and well before anthropology and sociology had been lain in the toolbox for successful historical enquiry - to write a history of the seven deadly sins. Huizinga was astonishingly 'modern' in his view about the kind of history that ought to be written: "If someone could write the history of vanity, he would command over half of cultural history." ${ }^{40}$ Forty years later Foucault wrote The History of Madness, focusing on how the concept of madness was envisioned from the Reanaissance to modernity, or, in "function of the separate subject in the broader cultural context"-just as Huizinga envisioned such kind of history to be written.

But what seems to me to be the extent of Huizinga's affinity to Foucault, is not merely a kind of history-making that he pointed at but did not do:

"The great divide in the perception of the beauty of life comes much more between the Renaissance and the modern period than between the Middle Ages and the Renaissance. The turnabout occurs at the point where art and life begin to diverge. It is the point where art begins to be no longer in the midst of life, as a noble part of the joy of life itself, but outside of life as something to be highly venerated, as something to turn to in moments of edification or rest. The old dualism separating God and the world has thus returned in another form, that of the separation of art and life. The Renaissance had managed to free itself from the rejection of all the joy of life as something sinful, but had not yet found a new way of separating the higher and lower enjoyments of life; the Renaissance wanted an unencumbered enjoyment of all of life. The new distinction is a compromise between the Renaissance and Puritanism that is at the base of modern spiritual attitudes. It amounted to a mutual capitulation in which the one side insisted on saving beauty while the other insisted on the condemnation of sin. Only after the Puritan worldview lost its intensity did the Renaissance perceptiveness to all the joys of life gain ground again; perhaps even more ground than before, because beginning with the eighteenth century there is a tendency to regard the natural per se as an element of the basically good." 41

Minds, views, practices, theories are all encompassed into an overarching gaze that is not confined to a period but is rather focused upon an idea through the various ages - that of the fracture between beauty and its negation-which in turn illuminates historical periods with a new perspective: such a passage easily might have been from The Order of Things.

Finally, I should like to examine briefly Foucault's concept of "discontinuity". How novel was it really and did its employment change historical thinking? As to its originality, discontinuity cannot be ascribed to Foucault, since it was Georges

${ }^{37}$ As opposed to the "New Cultural History" (NCH). The name appeared in the late 1980's, but Foucault was a foundational figure of NCH. (See Burke, 2008: pp. 51-76)

${ }^{38}$ Cited in Wintraub, 1996: p. 231.

${ }^{39}$ Cited in Weintraub, 1996: p. 231.

${ }^{40}$ Cited in Weintraub, 1996: p. 233.

${ }^{41}$ Huizinga, 1996: pp. 40-41.
Canguilhem, who introduced the concept of discontinuity to Foucault. Nevertheless, Canguilhem profited little from it, since he did not much avail himself of it in his work. Foucault's historical thought on the other hand, is inextricably tied to the notion of discontinuity; and many epigones have exaggerated Foucault's own attachment to it, hence the abutment of Foucault to Structuralism, which Foucault insistently rejected. "My problem was not at all to say 'Voilá long live discontinuity, we are in the discontinuous and a good thing too,' but to pose the question 'How is it that at certain moments and in certain orders of knowledge, there are these sudden take-offs, these hastenings of evolution, these transformations which fail to correspond to the calm, continuist image that is normally accredited?' It was these different regimes that I tried to identify and describe in The Order of Things." 42 Foucault's elucidation is significant, because too much has been made in the name of Foucault of the concepts of continuity and discontinuity. It is for this reason perhaps that Marcel Gauchet didn't concern himself with Foucault in Veyne's essay on him; he may have found that Foucault's historical lens were too heavily clouded with these concepts, which according to him were misleading:

"Two perspectives have normally been regarded as incompatible: the uniformity of human development and the existence of radical discontinuities within it. The word 'uniformity' does not mean continuity and does not mean that the same imperatives and ends have always prevailed everywhere. Conversely, discontinuity does not necessarily involve an irreducible plurality of instances and configurations, each one uniquely and impenetrably closed in on itself and the result of the world's unpredictable vagaries." ${ }^{43}$

For Structuralists, and other obdurate defenders of discontinuity, Gauchet's point is hard to shake off. I am inclined to agree with Gauchet about the relative meaninglessness of discontinuity per se because of Huizinga's memorable words about the same issue, "The image of the transition of a period to another is that of a long succession of waves rolling onto a beach, each of them breaking at a different point and a different moment. Everywhere the lines between the old and the new are different Anyone seeking in a transition a total unity of spirit capable of being stated in a simple formula will never understand it in all its expressions." 44 These words capture beautifully the pitfalls of seeking both a single, encompassing discontinuous aspect in history. However, it must be stressed that Foucault used the concept of discontinuity with much more parsimony, care, and nuance than some commentators have attributed to him; and to the extent that he did so, he is to be heeded, for in the hands of Foucault the analysis of intellectual discontinuity produced fertile results, from The Order of Things to History of Madness.

\section{Conclusion}

I have tried to investigate if and to what extent Foucault revolutionized history; and a few key points seem to have emerged. Let us start with Paul Veyne, who first proclaimed Foucault to be a revolutionary historian; we have seen that his essay is heavily slanted and offers a reading that is not completely faithful to Foucault's thinking. Firstly, Foucault was not the originator of the qualities that Veyne perceived to be unique in Foucault, for Ortega y Gasset, Johan Huizinga, Fustel de Coulanges, Max Weber, Emile Durkheim, and others, were

\footnotetext{
${ }^{42}$ Foucault, 2000b: p. 114.

${ }^{43}$ Gauchet, 1999: p. 15.

${ }^{44}$ Huizinga, 1959: pp. 282-286.
} 
precursors to Foucault's broad, interdisciplinary outlook, born out of a classical cultural preparation and an idiosyncratic vision of the human sciences. Secondly, Veyne did not always describe Foucault's thought accurately nor did he truly isolate its greatest merits; Foucault, as we have seen, despite his own declarations to the contrary, was not a strict empiricist. I would define his historical approach as a rare admixture of skepticism and hermeneutics. Such a combination allowed him to write books which from a strictly historiographical point of view are hybrids. The Order of Things, for example, recalls Max Weber's The Protestant Ethic and the Spirit of Capitalism: they both trace an idea in history, while illuminating the period(s) they examine, without giving emphasis to individuals as agents in history, yet accentuating the deepest recesses of human cognizance in an epoch.

Whether there was ever a man who has revolutionized history by himself is questionable; yet Foucault has left an indelible mark on the historian's craft: he has provided alternate ways of looking at it. We may certainly speak of and refer to 'Foucault's gaze'-a highly original slant on the issues he concentrated on, and, an example of sincerity. The seeds of his thought, thus, even that that is not devoted to historical issues, can be sown to fructify a kind of historian, who is "able to experience a violent, direct interest in things for their own sake."45

From a strictly historical perspective, Foucault has his merits and his faults. His books contain cues for rich historical enquiry that must be carried on; a book like the first volume of the History of Sexuality - his most "historical" work-is an exemplary study of the bourgeois ethos of the nineteenth century that few have penetrated as deeply. On the other hand, in the few pages about medieval law, in his lecture "Truth and Juridical Forms", the paucity of Foucault's knowledge of feudal law is flagrantly evident if we confront his observations with the equally succinct, yet magisterial and enlightening pages of Maitland's essay "History of English Law", ${ }^{46}$ Foucault's concepts of episteme and discontinuity seem at times mere instruments of his ambition for all-encompassing historical statements.

And so, Foucault did not revolutionize history. He did, however, modify our assumptions on how one might think about history. And yet, Clio wears a dress whose pattern is so varied, that, without a doubt, Foucault is permanently emblazoned on her serried vest.

\section{References}

Acton, J. E. E. (1886). German schools of history. The English Historical Review, 1, 7-42. doi:10.1093/ehr/I.I.7

Barzun, J. (1974). Clio and the doctors. Chicago: University of Chicago Press.

Benjamin, W. (1977). The Origin of German Tragic Drama. London: NLB.

Blanning, T. (2007). The Pursuit of Glory. New York: The Viking Press.

Bloc, M. (2005). Scritti sulla storia come scienza. Rome: Centro di Ricerca.

Burke, P. (2008). What is Cultural History? Cambridge: Polity.

Michel Foucault, M. (1994). The Order of Things: an Archaeology of the Human Sciences. New York: Vintage Press.

Foucault, M. (2000a). The Order of Things. In J. Faubon (Ed.), Aesthetics, Method, and Epistemology, New York: The New Press.

Foucault, M. (2000b). Truth and Power. In J. Faubion (Ed.), Power, New York: The New Press.

Foucault, M. (2007). Security, Territory, Population: Lectures at the Collège De France, 1977-1978. New York: Picador.

Foucault, M. (2010). The archaeology of knowledge; and, the discourse on language. New York: Vintage Press.

Gadamer, H. G. (2004). Truth and method. London: Continuum.

Gauchet, M. (1986). La nominalisme historien, A propos de "Foucault révolutionne l'histoire”, de Paul Veyne. Social Science Information, 25, 401-419. doi:10.1177/053901886025002005

Gauchet, M. (1999). The disenchantment of the world. New Jersey: Princeton University Press.

Huizinga, J. (1959). The problem of the renaissance. In Men \& Ideas, New York: Meridian Books, 243-287.

Huizinga, J. (1996). The Autumn of the Middle Ages. Chicago: The University of Chicago Press.

Ortega y Gasset, J. (1936). History as a system. In R. Klibansky (Ed.), History and Philosophy, Oxford: Clarendon Press, 283-322.

Veyne, P. (1978). Foucault revolutionizes history. In A. I. Davidson (Ed.), Foucault and His Interlocutors, Chicago: University of Chicago Press, 146-182.

Veyne, P. (2010). Foucault: His Thought, His Character. Cambridge: Polity.

Weintraub, K. J. (1966). Visions of Culture. Chicago: Chicago University Press.

\footnotetext{
${ }^{45}$ Huizinga, 1959: p. 287.

${ }^{46}$ See Maitland, F. W. (1957). History of English Law. Historical Essays.

London: Cambridge University Press.
} 